\title{
Production of bergenin, an active chemical constituent in the callus of Bergenia ciliata (Haw.) Sternb.
}

\author{
Umesh Krishna Shrestha ${ }^{1^{*}}$ and Bijaya Pant \\ Central Department of Botany, Trivhuban University, Kathmandu, Nepal \\ ${ }^{1}$ Current address: Department of Plant Resources, Ministry of Forest and Soil Conservation, Government of Nepal, Thapathali, \\ Kathmandu, Nepal
}

\begin{abstract}
In vitro culture of Bergenia ciliata (Haw.) Sternb. was carried out for the examination of bergenin content. Leaf explants were cultured in MS (Murashige and Skoog) basal media supplemented with or without phytohormones. The hormonal series maintained were in the range of $0-2 \mathrm{mg} \mathrm{l}^{-1}$ for BAP (6-benzyl amino purine) and 0-1.5 mg $\mathrm{I}^{-1}$ for NAA ( $\alpha$-naphthalene acetic acid). Bergenin content of in vitro grown tissues of $B$. ciliata was compared with that of wild plants collected from three different localities of Nepal. The best growth of callus and plantlets occurred in the media containing BAP $1.0 \mathrm{mg} \mathrm{l}^{-1}+\mathrm{NAA} 1.0 \mathrm{mg} \mathrm{l}^{-1}$ and BAP $1.5 \mathrm{mg} \mathrm{l}^{-1}+\mathrm{NAA}^{1.0} \mathrm{mg} \mathrm{l}^{-1}$. Production of bergenin was high in the media supplemented with $\left.1.0 \mathrm{mg} \mathrm{l}^{-1} \mathrm{BAP}+1.5 \mathrm{mg} \mathrm{l}^{-1} \mathrm{NAA}^{(3.40 \mu \mathrm{g} \mathrm{g}}{ }^{-1}\right)$ and $2.0 \mathrm{mg} \mathrm{l}^{-1}$ BAP $+1.5 \mathrm{mg} \mathrm{l}^{-1}$ NAA $\left(3.05 \mu \mathrm{g} \mathrm{g}^{-1}\right)$ under experimental condition. The bergenin content in the wild plants collected from Langtang, Jumla and Godawari was found to be $4.28 \mu \mathrm{g} \mathrm{g}^{-1}, 4.53 \mu \mathrm{g} \mathrm{g}^{-1}$ and $3.64 \mu \mathrm{g} \mathrm{g}^{-1}$ respectively. This study shows that the in vitro cultured callus of $B$. ciliata is capable of synthesizing bergenin in quantity comparable to that of the wild plant.
\end{abstract}

Key-words: callus, chemical content, HPTLC analysis, medicinal plant, tissue culture, Nepal Himalaya.

\section{Introduction}

Bergenia ciliata (Haw.) Sternb. (Saxifragaceae) is a high value medicinal plant of the Himalaya. It is a perennial herb with thick, stout, creeping rhizomes. It is found on moist rock ledges and rocky cliff in forest and shady banks from an altitude of 900 to $3600 \mathrm{~m}$ asl in the Himalaya. It is locally known as Pakhanbhed (in Nepali), the name derived from Sanskrit word - Pashanabheda which signifies its growth habit and habitat (Pashan meaning rock and bheda meaning piercing). B. ciliata is a threatened species in Nepal (Shrestha and Joshi 1996) due to commercial harvest and has been prioritized for conservation and economic development by the Government of Nepal (DPR 2008).

${ }^{*}$ Correspondence, e-mail: shres57tha@hotmail.com
Rhizomes of $B$. ciliata have variously been used as medicine for different diseases (Sinha et al. 2001; Baral and Kurmi 2006; DPR 2007). The active chemical has been identified as bergenin and various methods have been developed for its quantitative and semi-quantitative estimation (Anonymous 2002). High performance thin layer chromatography (HPTLC) has been used as the quantitative tool for the determination of bergenin content in the rhizome of Bergenia spp. (Bahl et al. 1974).

It has been shown that under some suitable conditions a plant cell can be activated to produce chemicals of medicinal value in vitro by means of tissue culture technique (Flores and Filner 1985; Chattopadhyay et al. 2004; Paudel and Pant 2006). This may have important implication, in the future, for the production of medicinally active secondary compounds in commercial scale (Goldstein 1980; Zenk 1991; Verpoorte 
et al. 1993; Ahmad et al. 2007). The yield of secondary products in cell culture has been reported to be equal to those of intact plants (Kreis and Reinhard 1989; Charlwood and Rhodes 1990; Andrade et al. 2004; Ahmad et al. 2007), rarely reaching as high as 10\% (Trease and Evans 2002). However, in most cases, the secondary metabolites in the tissue or cell culture remained in quantities lesser than that produced by intact plants (Zieg et al. 1983; Asai et. al. 1994; Trease and Evans 2002).

Although tissue culture technique has been used to propagate B. ciliata by some workers (e.g., Karki and Rajbahak 2008), the analysis of the callus of this species for bergenin content has not been reported. The present study was aimed to examine the potency of the callus formation of various parts of B. ciliata and assess the content of bergenin, the active principle, in callus grown in various combinations of BAP and NAA.

\section{Materials and Methods}

Healthy leaf segments $(3-5 \mathrm{~mm} \times 3-5 \mathrm{~mm})$, shoot tips (1-2 $\mathrm{mm}$ ) and root tips (3-5 $\mathrm{mm}$ ) of B. ciliata were taken from in vitro raised plants under aseptic condition following Karki and Rajbak (2007). Then, the explants were inoculated in the MS media supplemented with or without hormones. Hormonal media comprised of 0.0-2.0 $\mathrm{mg} \mathrm{l}^{-1} \mathrm{BAP}$ (6-benzyl amino purine) and $0.0-1.5 \mathrm{mg} \mathrm{l}^{-1} \mathrm{NAA}(\alpha$-naphthalene acetic acid) and their combinations. All the cultures were maintained at $25 \pm 2^{\circ} \mathrm{C}$ and daily photo period of $16 \mathrm{~h}$. Subculture was done only on the fraction of culture at the interval of three months as the callus grew very slowly.

Callus mass and proliferated shoots from each hormonal concentration were analyzed for bergenin content by HPTLC method (IDMA 2002; ICMR 2003). The tissue mass was shade dried and then ground to powder. Two grams of dried tissue was refluxed with methanol. After drying, the methanolic extract was again dissolved in $50 \mathrm{ml}$ of methanol. The extract was analyzed first by thin layer chromatograpy (TLC) using the pre-coated plates with silica $\mathrm{GF}_{254}$. Solvent used to develop the plate was toluene: ethyl acetate: acetone (2: 4:4). The spots were visualized by spraying concentrated sulphuric acid and heating for $80^{\circ} \mathrm{C}$ in an oven (the spots were visible as blue spots). The plates were observed in daylight where bergenin was visible as pink spots at $\mathrm{R}_{\mathrm{f}}=0.36$. Reference solution was prepared by dissolving $2.5 \mathrm{mg}$ of reference material (bergenin) obtained from Sigma (Ref. No. B6776) in $5 \mathrm{ml}$ of methanol.

For HPTLC, $5 \mu 1$ of the prepared extract was applied in thin layer plates (with silica $\mathrm{GF}_{254}$ ). It was then developed with the solvent system toluene: ethyl acetate: acetone (2: 4: 4). Standard of bergenin was also placed along the sample for quantitative analysis. TLC plates were scanned in Desaga CD-60 Densitometer at wavelength $254 \mathrm{~nm}$.

Rhizomes of $B$. ciliata were collected from natural populations at three different regions of Nepal: Langtang National Park (2280-3000 m asl) and Godavari Community forest (2300-2760 m asl), and Jumla (2370-3000 m asl). Langtang and Godavari lies in central Nepal and Juma in western Nepal. Rhizome samples were powdered, and $2 \mathrm{~g}$ of which were refluxed with methanol. Finally methanolic solution was prepared and analysed for bergenin content following the same methods as described above.

\section{Results}

\section{IN VITRO CULTURE AND THE FORMATION OF CALLUS}

The root tip and shoot tip failed to show any response in any of the culture media used, but leaf explants responded variously in growth and development of callus (Table 1). In the absence of NAA, hormonal media containing only BAP (at all concentrations) failed to initiate callus formation from leaf explants. However, hormonal media containing only NAA initiated callus growth with root like structures. However, stable cultures were not produced. In $0.5 \mathrm{mg} \mathrm{l}^{-1} \mathrm{NAA}$ alone (media no. 6), a slight evidence of callusing of the leaf explants was observed in 2 weeks and it took nearly a month for complete callusing.

At higher concentrations $\left(\geq 0.5 \mathrm{mg} \mathrm{l}^{-1}\right)$ of both BAP and NAA in MS medium, the explants responded variously in callus formation. However, the optimal concentrations of these hormones for callusing and organogenesis were $1.0 \mathrm{mg} \mathrm{l}^{-1} \mathrm{NAA}$ and $1.5 \mathrm{mg} \mathrm{l}^{-1}$ BAP. These hormonal concentrations were most appropriate for the plantlet proliferation. The cultures were maintained by sub-culturing the callus at the time interval of three months. Increase in NAA concentration promoted root differentiation and increase in BAP promoted shoot differentiation. However, high concentration $\left(2.0 \mathrm{mg} \mathrm{l}^{-1}\right) \mathrm{did}$ not support formation of callus and rejuvenation. 
Table 1. Growth of callus at different hormonal concentrations.

\begin{tabular}{|c|c|c|c|c|c|c|}
\hline \multicolumn{6}{|l|}{ NAA } & $2.0 \mathrm{mg} \mathrm{l}^{-1}$ \\
\hline \multirow{2}{*}{\multicolumn{2}{|c|}{$0 \mathrm{mg} \mathrm{l}^{-1 *}$}} & Callus 1 & Callus 2 & Callus 3 & Callus 4 & Callus 5 \\
\hline & & - & - & - & - & - \\
\hline \multirow{2}{*}{\multicolumn{2}{|c|}{$0.5 \mathrm{mg} \mathrm{l}^{-1}$}} & Callus 6 & Callus 7 & Callus 8 & Callus 9 & Callus 10 \\
\hline & & + & ++ & ++ & +++ & ++ \\
\hline \multirow{2}{*}{\multicolumn{2}{|c|}{$1.0 \mathrm{mg} \mathrm{l}^{-1}$}} & Callus 11 & Callus 12 & Callus 13 & Callus 14 & Callus 15 \\
\hline & & + & +++ & +++ & +++ & + \\
\hline \multirow{2}{*}{\multicolumn{2}{|c|}{$1.5 \mathrm{mg} \mathrm{l}^{-1}$}} & Callus 16 & Callus 17 & Callus 18 & Callus 19 & Callus 20 \\
\hline & & + & ++ & +++ & +++ & ++ \\
\hline
\end{tabular}

*MS basal medium

- no callusing, + slight callusing $(<5 \mathrm{~mm}$ in $1 \mathrm{month}),++$ moderate callusing ( $5 \mathrm{~mm}$ to $10 \mathrm{~mm}$ in $1 \mathrm{month}),+++$ profuse callusing $(>10 \mathrm{~mm}$ in 1 month). Culture condition: $25 \pm 20^{\circ} \mathrm{C}$ and $16 \mathrm{~h}$ photo period daily.

Table 2. Presence of bergenin in callus cultured in different hormonal condition.

\begin{tabular}{lccccc}
\hline \multicolumn{1}{c}{ BAP } & $0 \mathrm{mg} \mathrm{l}^{-1^{*}}$ & $0.5 \mathrm{mg} \mathrm{l}^{-1}$ & $1.0 \mathrm{mg} \mathrm{l}^{-1}$ & $1.5 \mathrm{mg} \mathrm{l}^{-1}$ & $2.0 \mathrm{mg} \mathrm{l}^{-1}$ \\
$\mathrm{NAA}$ & & & & & \\
\hline $0 \mathrm{mg} \mathrm{l}^{-1^{*}}$ & & & & & \\
$0.5 \mathrm{mg} \mathrm{l}^{-1}$ & Callus 6 & Callus 7 & Callus 8 & Callus 9 & Callus 10 \\
& + & + & + & + & + \\
$1.0 \mathrm{mg} \mathrm{l}^{-1}$ & Callus 11 & Callus 12 & Callus 13 & Callus 14 & Callus 15 \\
& ++ & + & +++ & + & ++ \\
$1.5 \mathrm{mg} \mathrm{l}^{-1}$ & Callus 16 & Callus 17 & Callus 18 & Callus 19 & + Callus 20 \\
& + & + & +++ & + & +++ \\
\hline
\end{tabular}

*MS basal medium

+ presence of bergenin in trace amount, ++ presence in low amount $\left(<0.5 \mu \mathrm{g} \mathrm{g}^{-1}\right),+++$ presence in moderate amount $\left(>0.5\right.$ to $\left.<2.0 \mu \mathrm{g} \mathrm{g} \mathrm{g}^{-1}\right),++++$ presence in amount comparable to natural sample ( $>2.0$ to $\left.4 \mu \mathrm{g} \mathrm{g}^{-1}\right)$.

\section{CHEMICAL ANALYSIS OF THE CALLUS}

The qualitative analysis showed the presence of bergenin in all the calli (Table 2). It was indicated by the blue spot when the TLC plates were developed with concentrated sulphuric acid. However, the quantitative analysis by densitometer (HPTLC) showed only trace amount of bergenin in most of the treatments, except in calli 11 13, 15, 18 and 20 (Table 3). In those calli, bergenin content ranged 0.27-3.40 $\mu \mathrm{g} \mathrm{g}^{-1}$. Bergenin content in the rhizomes of $B$. ciliata from natural populations, however, varied from 3.64 to $4.53 \mu \mathrm{g} \mathrm{g}^{-1}$. It was found that bergenin produced by the callus 18 (treated with $\mathrm{MS}+1.5 \mathrm{mg} \mathrm{l}^{-1} \mathrm{NAA}+1.0 \mathrm{mg} \mathrm{l}^{-1} \mathrm{BAP}$ ), and callus 20 (treated with $\mathrm{MS}+1.5 \mathrm{mg} \mathrm{l}^{-1} \mathrm{NAA}+2.0 \mathrm{mg} \mathrm{l}^{-1} \mathrm{BAP}$ ), the amount being 3.40 and $3.05 \mu \mathrm{g} \mathrm{g}^{-1}$, respectively, were comparable with the amount of bergenin present in the natural sample collected from Godawari (3.64 $\left.\mu \mathrm{g} \mathrm{g}^{-1}\right)$ (Table 3).

\section{Discussion}

This study showed that NAA (auxin) and BAP (cytokinin) are essential for the induction and development of callus in $B$. ciliata. The most effective cultur media for callus formation and proliferation of plant was MS media supplemented with $1.0 \mathrm{mg} \mathrm{l}^{-1} \mathrm{NAA}$ and $1.5 \mathrm{mg} \mathrm{l}^{-1} \mathrm{BAP}$. These results were similar to Karki and Rajbahak (2007). They reported regeneration of plantlets of Bergenia ciliata using MS media supplemented with $0.5 \mathrm{mg} \mathrm{l}^{-1} \mathrm{BAP}, 0.1 \mathrm{mg} \mathrm{l}^{-1} \mathrm{NAA}$ and $100 \mathrm{mg} \mathrm{l}^{-1}$ Adenine sulphate. Brar and Khush (1994) and Brown and Thorpe (1994) also reported that at higher concentrations both NAA and BAP did not support formation of callus and rejuvenation. The higher concentration of NAA and BAP might have inhibitory effect in the tissue differentiation (Brown and Thorpe 1994). 
Table 3. Bergenin content in in vitro grown tissues of B. ciliata.

\begin{tabular}{clc}
\hline $\begin{array}{c}\text { Callus } \\
\text { no }\end{array}$ & Treatment & $\begin{array}{c}\text { Amount of } \\
\text { bergenin } \\
\left(\mu \mathrm{g} \mathrm{g}^{-1}\right)\end{array}$ \\
\hline 11 & $\mathrm{MS}+1.0 \mathrm{mg} \mathrm{l}^{-1} \mathrm{NAA}$ & 0.28 \\
13 & $\mathrm{MS}+1.0 \mathrm{mg} \mathrm{l}^{-1} \mathrm{NAA}+1.0 \mathrm{mg} \mathrm{l}^{-1} \mathrm{BAP}$ & 1.81 \\
15 & $\mathrm{MS}+1.0 \mathrm{mg} \mathrm{l}^{-1} \mathrm{NAA}+1.5 \mathrm{mg} \mathrm{l}^{-1} \mathrm{BAP}$ & 0.27 \\
18 & $\mathrm{MS}+1.5 \mathrm{mg} \mathrm{l}^{-1} \mathrm{NAA}+1.0 \mathrm{mg} \mathrm{l}^{-1} \mathrm{BAP}$ & 3.40 \\
20 & $\mathrm{MS}+1.5 \mathrm{mg} \mathrm{l}^{-1} \mathrm{NAA}+2.0 \mathrm{mg} \mathrm{l}^{-1} \mathrm{BAP}$ & 3.05 \\
\hline
\end{tabular}

Table 4. Bergenin content in the rhizomes of Bergenia ciliata collected from three different regions of Nepal.

\begin{tabular}{lcc}
\hline Geographical location & Altitude (m asl) & $\begin{array}{c}\text { Amount of } \\
\text { bergenin }\left(\mu \mathrm{g} \mathrm{g}^{-1}\right)\end{array}$ \\
\hline Langtang & $2280-3000$ & 4.28 \\
Jumla & $2370-3000$ & 4.53 \\
Godawari & $2300-2760$ & 3.64 \\
\hline
\end{tabular}

We observed only trace amount of bergenin in most the in vitro grown calli. However, bergenin contents in callus no. 18 and 20 were comparable with that in the samples collected from the natural habitats. Earlier studies have shown that the yield of secondary compounds produced in cell culture would be either much lower (Zieg et al. 1983; Asai et al. 1994; Trease and Evans 2002), equal (Kreis and Reinhard 1989; Charlwood and Rhodes 1990; Andrade et al. 2004; Ahmad et al. 2007), or higher (Trease and Evans 2002) than those in intact plants. Ahmad et al. (2007) studied production of podophyllotoxin in callus culture (MS media with combinations of NAA and BAP) of Podophyllum hexandrum and reported low yield (up to $0.79 \%$ dry weight) in the callus compared to natural root sample (5.48\%). Jhang et al. (1974) found panquilin content in callus and suspension culture of Panax quinqueolium and $P$. ginseng to be $1.3 \%$ of fresh weight, representing about half of the amount of panquilin present in ginseng root of natural populations. Hence, from this study it can be concluded that bergenin can be produced in in vitro grown callus in the amount comparable to the samples from natural habitat. This could be an alternative to minimize the exploitation of natural population of B. ciliata.

As an attempt to increase the concentration of secondary metabolites in in-vitro culture callus, precursors have been used during tissue culture. For example, addition of coniferin (a polypropane) in the culture of Podophyllum hexandrum improved podophllotoxin synthesis by 12.8 folds (Chattopadhyay et al. 2003). Similarly, quinoline yield has been increased by L-tryptophan precursor feeding to Chichona ledgeriana (Trease and Evans 2002). However, various authors have also indicated the instability of cell culture line. Tissue cultured cells may produce the compounds not found in the plant itself. A new caumarin, rutacultin has been isolated from suspension culture of Ruta graveolens (Trease and Evans 2002). Two new chalcones have been characterized from tissue culture of Glycyrrihza echinita (Charlwood and Rhodes 1990; Trease and Evans 2002). Similarly, Feforeyev et al. (2008) found significant amount of isoflavonides produced by calus of Maackia amurensis sub-cultured from stable cell line. Thus, further study is needed to investigate whether the callus culture can yield a cell line that may produce bergenin in significantly higher concentration similar to callus culture of Maackia amurensis as done by Fedoreyev et al. (2008).

\section{Acknowledgements}

We gratefully acknowledge Central Department of Botany, Tribhuvan University, Kirtipur, Kathmandu and Department of Plant Resources of Ministry of Forest and Soil Conservation, Government of Nepal for providing the facilities to conduct this research. Our sincere thanks are due to S.K. Ghimire for critically going through this manuscript and providing valuable suggestions. We also thank R. Ranjitkar, D.L. Shrivastav, D.M. Shakya and M.S. Thapamagar for providing help during this research.

\section{References}

Ahmad R., Sharma V.K., Rai A.K., Shivananda R.D. and Shivananda B.G. 2007. Production of lignans in callus culture of Podophyllum hexandrum. Tropical Journal of Pharmaceutical Research 6: 803-808.

Andrade L.S., Lopes S.O., Zuanazzi J.A.S., Rech S.B. and Henriques A.T. 2004. Pilocarpine accumulation on Pilocarpus pennatifolius tissue culture. Brazilian Journal of Pharmaceutical Sciences 40: 437-439.

Anonymous. 2003. Quality Standards of Indian Medicinal Plants. Monograms Vol. 1. Indian Council of Medical Research, New Delhi, India.

Anonymous. 2002. Indian Herbal Pharmacopoeia. Revised New Edition, Vol. 1. Academic Indian Drug Manufacture's Association, Mumbai, India. 
Asai I., Yoshihira K., Omoto T., Sakui N. and Shimomura K. 1994. Growth and monoterpene production in shoot culture and regeneration of Mentha arvensis. Plant Tissue Culture Letters 11: 218-225.

Bahl C.P., Murari R., Parthasarathy M.R. and Seshadri T.R. 1974. Components of Bergenia strecheyi and B. ligulata. Indian Journal of Chemistry 12: 1038-1039.

Baral S.R. and Kurmi P.P. 2006. A Compendium of Medicinal Plants of Nepal. Mrs. Rachana Sharma, Kathmandu, Nepal.

Brar D.S. and Khush G.S. 1994. Cell and tissue culture for plant improvement. In: In vitro Mechanism of Plant Growth and Improved Productivity. Modern Approaches (A.S. Basra, ed.), pp. 229-278. Marcel Dekker Inc., New York, Basel, Hong Kong.

Brown, D.C.W. and Thorpe T.A. 1994. Crop improvement through tissue culture. World Journal of Microbiology and Biotechnology 11: 409-415.

Charlwood B.V. and Rhodes M.J. 1990. Secondary Products from Plant Tissue Culture. Proceedings of a Phytochemical Society of Europe Symposiums. Clarendon Press, Oxford, UK.

Chattopadhyay S., Bisaria V.S., Bhojwani S.S. and Srivastava A.K. 2003. Enhanced production of podophyllotoxin by fedbatch cultivation of Podophyllum hexandrum. The Canadian Journal of Chemical Engineering 8: 1011-1018.

Chattopadhyay S., Srivastava A.K. and Bisaria V.S. 2004. Production of phytochemicals in plant cell bioreactors. In: Plant Biotechnology and Molecular Markers (S. Srivastava and A. Narula, eds.), pp: 117-128. Anamaya Publishers, New Delhi, India.

DPR. 2007. Medicinal Plants of Nepal. Revised edition. Bulletin of the Department of Plant Resources No 28. Department of Plant Resources (DPR), Ministry of Forest and Soil Conservation, Government of Nepal, Kathmandu, Nepal.

DPR. 2008. Priority List of Plants for Developmental Purpose (2008). Department of Plant Resources (DPR), Ministry of Forest and Soil Conservation, Government of Nepal, Kathmandu, Nepal.

Fedoreyev S.A., Bulgakov V.P., Grishchenko O.V., Veselova M.V., Krivoschekova O.E., Kulesh N.I., Denisenko V.A., Tchernoded G.K. and Zhuravlev Y.N. 2008. Isoflavonoid composition of a callus culture of the relict tree Maackia amurensis Rupr. et Maxim. Journal of Agricultural and Food Chemistry 56: 7023-7031.

Flores H.E. and Filner P. 1985. Metabolic relationships of putrescine, GABA and alkaloids in cell and root cultures of Solanaceae. In: Primary and Secondary Metabolism of Plant Cell Cultures (K.H. Neumann, W. Barz and E. Reinhard, eds.), pp 174-196. Springer Verlag, Berlin, Germany.

Goldstein W. 1980. Plant Tissue Culture as a Source of Biochemicals. C.R.C. Press. Boca Raton, Florida, USA.

Jhang J.J., Staba E.J. and Kim J.Y. 1974. American and Korean ginseng tissue cultures: growth, chemical analysis, and plantlet Production. In Vitro 9: 253-259.

Karki A. and Rajbahak S. 2007. Micropropagation of Bergenia ciliata (Haw.) Sternb. through leaf culture. Bulletin of Department of Plant Resources, Kathmandu 29: 35-37.

Kreis W. and Reinhard E. 1989. The production of secondary metabolites by plant cells cultivated in bioreactors. Planta Medica 55: 409-416.

Paudel B.R. and Pant B. 2006. Micropropagation and comparative study of chemical components of essential oils of in vitro and in vivo grown Mentha spicata L. Nepal Journal of Science and Technology 7: 71-75.

Shrestha T.B. and Joshi R.M. 1996. Rare, Endemic and Endangered Plants of Nepal. WWF Nepal Programme, Kathmandu, Nepal.

Sinha S., Murugesan T., Maiti K., Rahaman G.J., Pal M. and Saha B.P. 2001. Evaluation of anti-inflammatory potential of Bergenia ciliata Sternb. rhizome extract in rats. Journal of Pharmacy and Pharmacology 53: 193-196.

Trease G.E. and Evans W.C. 2002. Pharmacogonsy. $15^{\text {th }}$ Edition. Saunders Company, Philadelphia, USA.

Verpoorte R., Heijfen R. van der and Schripsema J. 1993. Plant cell biotechnology for the production of alkaloids: Present status and prospects. Journal of Natural Products 56: 186189.

Zenk M.H. 1991. Chasing the enzyme of secondary metabolism: plant cell culture as a pot of gold. Phytochemistry 30: 38613863.

Zieg R.G., Zito S.W. and Staba E.J. 1983. Selection of high pyrethrin producting tissue cultures. Journal of Medical Plant Research 48: 88-91. 